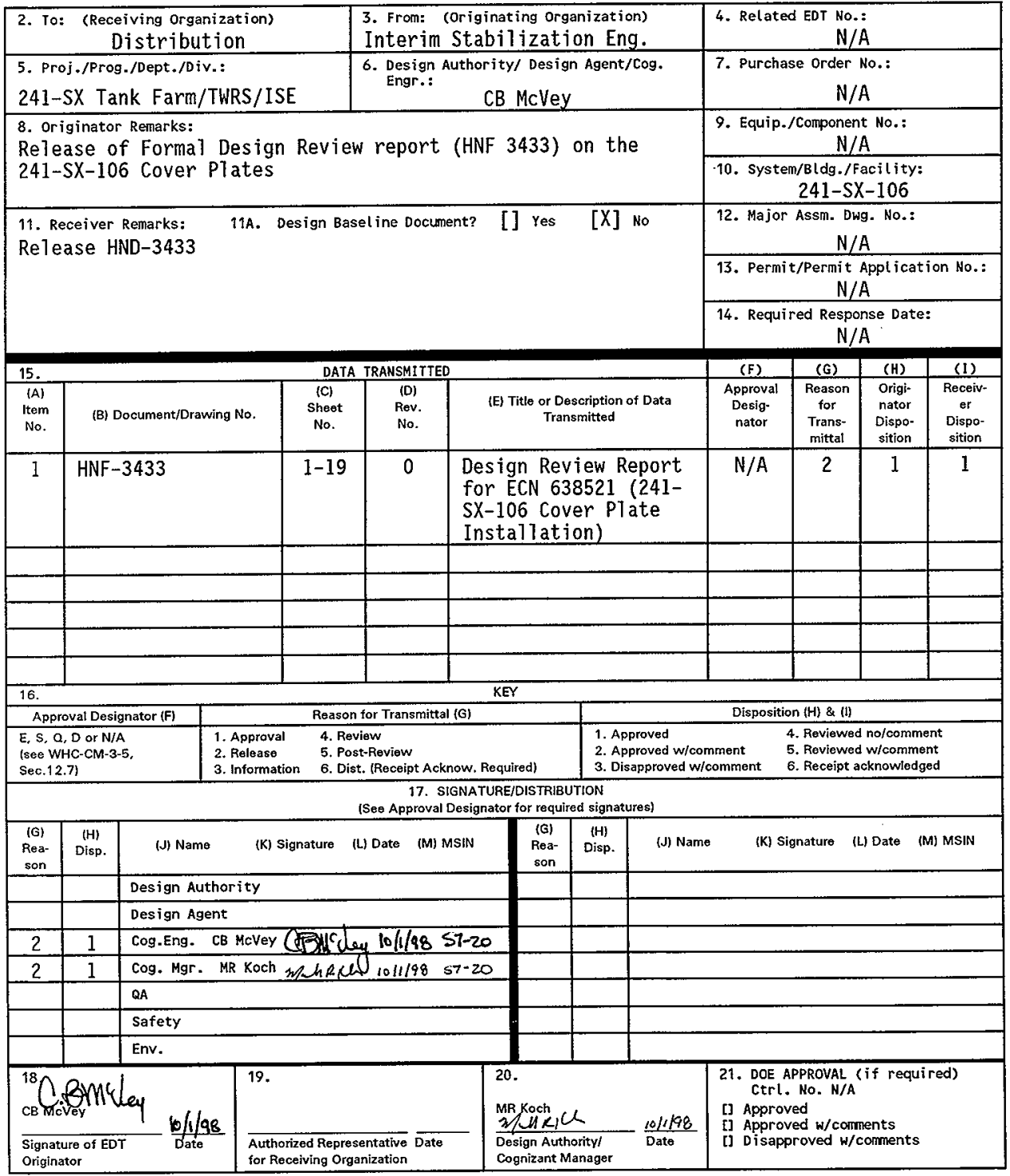


HNF-3433, Rev. 0

\title{
DESIGN REVIEW REPORT FOR ECN 638521 (241- SX-106 COVER PLATE INSTALLATION)
}

\author{
C. B. MCVEY
}

Lockheed Martin Hanford Company, Richland, WA 99352

U.S. Department of Energy Contract DE-AC06-96RL13200

624831

EDT/ECN: 624829/638521 UC: 500

Org Code: 74920 Charge Code: NIWGD

B\&R Code: EW3120071 Tota1 Pages: 19

Key Words: 24l-SX-106, DESIGN REVIEW REPORT, COVER PLATES

Abstract: The design for the cover plates on 241-SX-106 was reviewed on $9 / 10 / 98$. A11 comments were resolved to the satisfaction of the reviewers. A design calculation for seismic movement was performed and resulted the a design addition to prevent cover block movement. Also calculations were performed for radiological design and are included. The formal design review has no outstanding action items remaining and supports the use of 2" steel cover plates to provide personnel, shielding and spray knock down protection (as required by the BIO).

TRADEMARK DISCLAIMER. Reference herein to any specific commercial product, process, or service by trade name, trademark, manufacturer, or otherwise, does not necessarily constitute or imply its endorsement, recommendation, or favoring by the United states Government or any agency thereof or its contractors or subcontractors.

Printed in the United States of America. To obtain copies of this document, contact: Document Control services, P.0. Box 950, Mailstop H6-08, Richland WA 99352, Phone (509) 372-2420;

Fax (509) 376-4989.
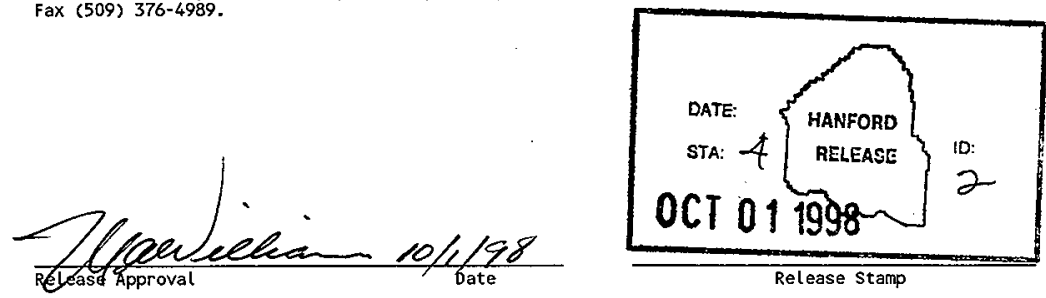

Approved for Public Release 


\section{TABLE OF CONTENTS}

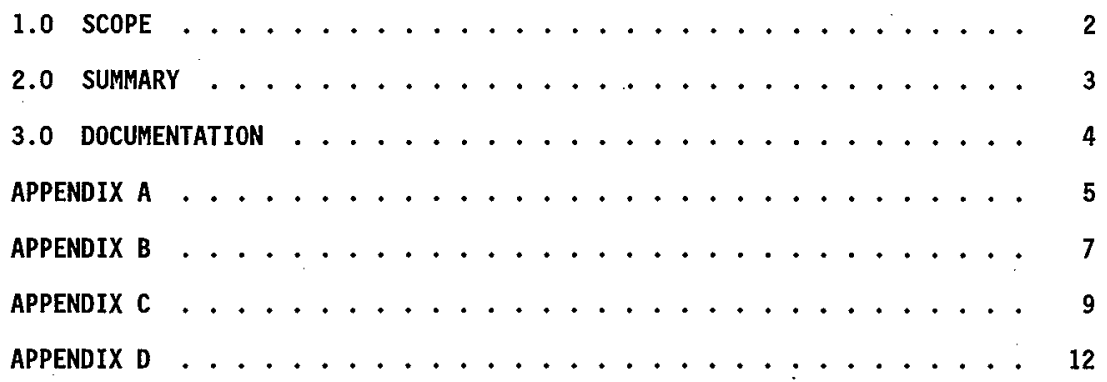




\subsection{SCOPE}

A design review meeting was held to review ECN 612026. During the review meeting it was determined to release ECN 612026 as a fabrication ECN only and to issue ECN 638521, 241-SX-106 Cover Plate Installation as the installation ECN. The cover plates for the 241-SX-106 pump pit are considered safety class items (HNF-SD-WM-BI0-001, 5.3.2.20) since they perform the function as a transfer system cover.

Document.s Reviewed: 1) ECN-638521, 241-SX-106 Cover P1ate Insta11ation

2) USQ TF-98-0607, IS: 241-SX-106 - Preparation for Installation of Saltwell Pumping Equipment

3) Dose Rate Reduction Due to Installation of 2" Steel Cover Plate At 241-SX-106 Pump Pit, $9 / 23 / 98$

4) Design Calculation, 241-SX-106 Cover P1ate Seismic Restraints, 9/21/98

The ECN provided the layout of the plates in relation to the pump pit and the existing concrete key block. It showed the general locations of the seismic restraints and the design of the restraints as required by the calculations (Appendix D).

The USQ (TF-98-0607, Rev 5) provided the screening for the cover plates and was found to have a11 "No" or "N/A" responses which showed that a Determination was not required.

The Dose Rate Reduction calculation provided documentation of the dose rate due to the removal of the concrete cover block and replacing it with a 2 " steel plate. The calculation also provided documentation of the Life Cycle Exposure Differential which showed that it was $>1$ person-REM (Appendix C).

The Design Calculation provided seismic calculation for the restraints that are being $\mathrm{placed}$ on the cover plates (Appendix D).

A11 documents are related to the Interim Stabilization program for Saltwe11 Pumping of 241-SX-106 tank in SX Tank Farm.

The objectives of the review were to establish design approval for the safety class cover plates on 241-SX-106. 


\subsection{SUMMARY}

The design review meeting was held on $9 / 10 / 98$. The meeting minutes are attached in Appendix B. A11 comments were recorded either by RCR comments or by the meeting minutes. An additional request was made by the Design Authority to provide seismic calculations on the cover plate clips. The conclusion of the meeting was that the design was approved with the incorporation of the comments from the RCR from a previous review meeting on cover plates and meeting minutes.

No outstanding action items remain on the design for the cover plates for 241-SX-106. 


\title{
3.0 DOCUMENTATION
}

Design Review Committee Members:
G. P. Janicek
M. R. Koch
C. B. McVey
T. J. Vol kman
L. S. Krogsrud
P. C. Miller
D. D. Wiggins
J. N. Doeler
M. R. Brown

\author{
Design Authority \\ Cognizant Manager - ISE \\ Cognizant Engineer - ISE \\ Quality Assurance \\ Safety \\ Environmenta1 \\ Mechanical - ISE \\ Cognizant Engineer - SX Farm \\ Mechanical Engineer - SX Farm
}

Documents:

Engineering Data Transmittal, 624829

Meeting Minutes, Distribution, dated 9/10/98

Does Rate Reduction Due to Installation of 2" Steel Cover P1ate At 241SX-106, D. J. Foust, dated September 25, 1998.

Design Calculation, 241-SX-106 Cover PTate Seismic Restraints, J. Elsen, dated $9 / 21 / 98$ 
HNF-3433, Rev. 0

Page 6 of 19

APPENDIX A

ENGINEERING DATA TRANSMITTAL

624829 
2. To: (Receiving Organization)

Distribution

5. Proj./Prog./Dept./Div.:

241-SX Tank Farm/TWRS/ISE

8. Originator Remarks:

\section{4 atalos 18}

Review and approval of ECN 61-2026, which provides the design for the cover plates for 241-SX-106.

\section{Receiver Remarks:}

11A. Design Baseline Document? $[\mathrm{x}$ Yes $\square$ No

If unable to attend, please send an alternate.
3. From: (Originating Organization)

Interim Stabilization Engineering

6. Design Authority/Design Agent/Cog. Engr.:

GP Janicek/CB McVey
4. Related EDT No.:

$\mathrm{N} / \mathrm{A}$

7. Purchase Order No:

$\mathrm{N} / \mathrm{A}$

9. Equip./Component No:

$\mathrm{N} / \mathrm{A}$

10. System/Bldg./Facility:

$241-\$ X-106$

12. Major Assm. Dwg. No.:

$\mathrm{N} / \mathrm{A}$

13. Permit/Permit Application No.:

$\mathrm{N} / \mathrm{A}$

14. Required Response Date:

$9 / 16 / 98$

15.

DATA TRANSMITTED

\begin{tabular}{|c|c|}
\hline $\begin{array}{c}\text { (A) } \\
\text { lem } \\
\text { No. }\end{array}$ & (B) DocumentDrawing No. \\
\hline 1 & ECN 612026638521 cul \\
\hline & \\
\hline & \\
\hline & \\
\hline & \\
\hline & \\
\hline
\end{tabular}

(C) Sheet (D) Rev.

(E) Title or Description of Data Transmitted

(F)

(G)

\begin{tabular}{|c|c|c|c|}
\hline $\begin{array}{l}\text { Approval } \\
\text { Desig- } \\
\text { nator }\end{array}$ & $\begin{array}{c}\text { Reason } \\
\text { for Trans } \\
\text { mittal }\end{array}$ & $\begin{array}{c}\text { Origi- } \\
\text { nator } \\
\text { Dispo- } \\
\text { stion }\end{array}$ & $\begin{array}{c}\text { Receiv- } \\
\text { er } \\
\text { Dispo- } \\
\text { sition }\end{array}$ \\
\hline$x$ & 1 & 1 & \\
\hline
\end{tabular}

16.

\begin{tabular}{|c|c|}
\hline $1-87$ & 0 \\
\hline & \\
\hline & \\
\hline & \\
\hline
\end{tabular}

241-SX-106 COVER PLATES

$241-5 X-106$ COVER PLATES

KEY

\begin{tabular}{|c|c|c|c|c|}
\hline Approval Designator (F) & \multicolumn{2}{|r|}{ Reason for Transmittal (G) } & \multicolumn{2}{|c|}{ Disposition (H) \& (I) } \\
\hline $\begin{array}{l}\text { ES, } Q \text { D OR N/A } \\
\text { Sec. } 12.7)\end{array}$ & $\begin{array}{l}\text { 1. Approval } \\
\text { 2. Release } \\
\text { 3. information }\end{array}$ & $\begin{array}{l}\text { 4. Review } \\
\text { 5. Post-Review } \\
\text { 6. Dist. (Receipt Acknow. Required) }\end{array}$ & $\begin{array}{l}\text { 1. Approved } \\
\text { 2. Approved w/comment } \\
\text { 3. Disapproved w/comment }\end{array}$ & $\begin{array}{l}\text { 4. Reviewed no/comment } \\
\text { 5. Reviewed w/comment } \\
\text { 6. Receipt acknowledged }\end{array}$ \\
\hline
\end{tabular}
17.

(See Approval Designator for required signatures)
(SIGNATURE

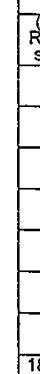

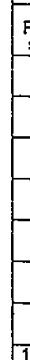$$
1
$$

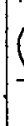

\begin{tabular}{l|c|ll}
$\begin{array}{c}\text { G) } \\
\text { ea- } \\
\text { on }\end{array}$ & $\begin{array}{c}\text { (H) } \\
\text { Disp. }\end{array}$ & (J) Name & (K) Signatur \\
\hline 1 & 2 & Design Authority GP JANICEK \\
\hline 1 & 1 & Cog. Eng. CB MCVEY \\
\hline 1 & 1 & Cog. Mgr. MR KOCH \\
\hline 1 & 1 & QA & TJ VOLKMAN \\
\hline 1 & 1 & Safety & LS KROGSRUD \\
\hline 1 & 1 & Env. & PC MILIER \\
\hline
\end{tabular}

8.

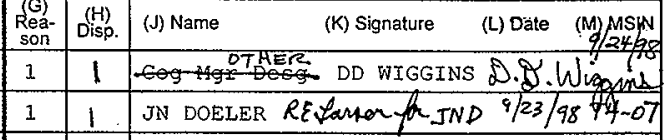

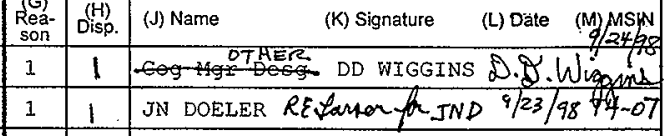

21. DOE APPROVAL (if required)

Ctrl No.

$\mathrm{N} / \mathrm{A}$

$\square$ Approved

$\square$ Approved w/comments

$\square$ Disapproved w/comments $\mathrm{BD}-7400-172-1$ 


\section{APPENDIX B}

MEETING MINUTES

DESIGN REVIEW MEETING ECN 612026, 241-SX-106 COVER PLATES 
HNF-3433, REV. 0

Page 9 of 19

\section{MEETING MINUTES}

SUBJECT: DESIGN REVIEW MEETING ECN 612026, 241-SX-106 COVER PLATES

\begin{tabular}{|c|c|c|c|c|c|}
\hline $\begin{array}{l}\text { TO: } \\
\text { DISTRIBUTION }\end{array}$ & & & $\begin{array}{l}\text { BUILDIN } \\
2704 \mathrm{H}\end{array}$ & 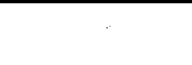 & \\
\hline $\begin{array}{l}\text { FROM: } \\
\text { Interim Stabi }\end{array}$ & ion & & $\begin{array}{l}\text { CHAIRMA } \\
\text { C. B. }\end{array}$ & & \\
\hline DEPARTMENT-OPERATIO & ONENT & $\begin{array}{l}\text { AREA } \\
200-E\end{array}$ & SHIFT & $\begin{array}{l}\text { DATE OF MEETING } \\
09 / 16 / 98\end{array}$ & $\begin{array}{c}\text { MUMBER ATTENDING } \\
5\end{array}$ \\
\hline Distribution: & $\begin{array}{l}\text { MH } \\
\text { JN } \\
\text { GP } \\
\text { MR } \\
\text { LS } \\
C B \\
\text { PC } \\
\text { RW } \\
\text { TJ } \\
\text { WF } \\
\text { DD }\end{array}$ & & & & . \\
\hline
\end{tabular}

This design review meeting was called in response to a field condition on 241-SX-106. The cover blocks on the pump pit had core drilled holes which did not align with the saltwell jet pump. This misalignment required two new 2" steel plates to be fabricated and installed on the pump pit after the key block was moved to come into alignment with the pump.

The design review was for the fabrication of the plates and installation. Review Comment Records were not taken for this review. The comments on a previous review (ECN 638517) were incorporated onto ECN 638521. Comments were taken during the meeting. These comments are recorded as follows:

1) Material certifications on the steel would not be required since the critical loading analysis was provided in the ECN on Page 7.

2) Due to the urgency for ordering the material and fabrication, this ECN should be separated into a fabrication ECN (612026) and an installation ECN (638521).

3) The installation ECN (638521) must have a Dose Rate calculation done and a Life Cycle Exposure Differential performed as part of the Design Review Report.

4) The installation ECN (638521) shall also have a seismic analysis performed on the restraints. This was discussed as to the requirement. After the discussion it was decided that it would be good engineering practice to provide as backup in the Design Review Report. 
HNF-3433, Rev. 0

Page 10 of 19

APPENDIX C

DOSE RATE REDUCTION

DUE TO INSTALLATION OF 2" STEEL.

COVER PLATE AT 241-SX-106 PUMP PIT 


\section{Scope}

This document describes the determination of the expected dose rate over the 241-SX106 pump pit after the installation of a $5.1 \mathrm{~cm}$ ( 2 inch) cover plates. The existing concrete cover block must be offset from its original position to align the pump valve access ports. The remaining pit opening will be covered by $5.1 \mathrm{~cm}$ ( 2 inch) steel plate.

\section{Assumptions}

- Based on current radiological survey reports, the maximum unshielded dose rate over the area of the pump pit to be covered by the carbon steel plate is 200 $\mathrm{mrem} / \mathrm{hr}$.

- The majority of the penetrating radiation from the pump pit is due the $0.662 \mathrm{Mev}$ gamma emitted by the ${ }^{137 m} \mathrm{Ba}$ daughter of ${ }^{137} \mathrm{Cs}$.

- The half-value layer for ${ }^{137} \mathrm{Cs}$ in iron is approximately $1.9(0.75 \mathrm{inch})^{1}$.

\section{Calculation}

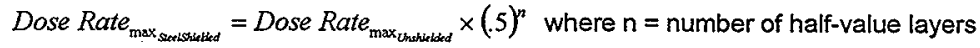

$$
n=\frac{5.1 \mathrm{~cm}}{1.9 \mathrm{~cm}}=2.7
$$

Dose Rate ${\text { max } \text { sertstirited }}=\frac{200 \mathrm{mrem}}{\mathrm{hr}} \times(.5)^{2.7}=\frac{31 \mathrm{mrem}}{\mathrm{hr}}$

\section{Life Cycle Exposure Differential}

- Maximum personnel occupancy over the carbon steel cover plate is expected to be 15 minutes $(0.25 \mathrm{hr})$ per week.

- $\mathrm{SX}-106$ pumping schedule is 502 days (conservative estimate of 2 years will be used for calculation).

- Half-value layer of concrete cover block to be replace by the carbon steel plates is 5 cm (2 inches) ${ }^{2}$.

- Thickness of concrete cover block replaced by carbon steel plate is $38 \mathrm{~cm}$ (15 inches).

$n=\frac{38 \mathrm{~cm}}{5 \mathrm{~cm}}=7.6$

Dose Rate ConcreleShielded $_{\text {. }}=\frac{200 \mathrm{mrem}}{\mathrm{hr}} \times(.5)^{7.6}=\frac{1 \mathrm{mrem}}{\mathrm{hr}}$

1,2 Bernard Shleien, The Health Physics and Radiological Health Handbook, Revised Edition, 1992, page192 
Dose Rate Reduction

Due to Installation of

2" Steel Cover Plate

At 241-SX-106 Pump Pit

September 25, 1998, Page 2 of 2

Prepared By: D. J. Foust Hasil Hond

Senior Health Physicist, TWRS Radiologica!

Engineering \& Technical Support

$$
\begin{aligned}
& \frac{31 \mathrm{mrem}}{h r}-\frac{1 \mathrm{mrem}}{h r}=\frac{30 \mathrm{mrem}}{\mathrm{hr}} \\
& \frac{30 \mathrm{mrem}}{\mathrm{hr}} \times \frac{0.25 \mathrm{hr}}{\text { week }} \times \frac{52 \text { week }}{y r} \times 2 y r=780 \mathrm{mrem}
\end{aligned}
$$

\section{Conclusion}

The calculated exposure increase due to the proposed installation of the carbon steel cover plate is 780 mrem for the life cycle of the project. This calculated exposure is based on several conservative assumptions. Actual dose rates should be verified by field measurements after installation of the cover plate. Exposure may be further reduced by administratively limiting personnel occupancy over the cover plate. 
HNF-3433, Rev. 0

Page 13 of 19

APPENDIX D

DESIGN CALCULATION

241-SX-106 COVER PLATE SEISMIC RESTRAINTS 
(1) Drawing

(2) Doc. No.

(3) Page of

(4) Building

(5) Rev.

(6) Job No.

(7) Subject 241-5x-106 COVER

PLATT SEISMIC: RESTRAINTS

(8) Originator

(3) Jan and and

(9) Checker

Date

9.21 .98

Date

$9-7>-98$

(10)

A seismic analysis is required for the installation of steel cover block plates on the 241-SX-106 pump pit. The SX-106 pump pit requires the installation of two steel plates to act as spray control and radiation shielding covers. The layout of the pump pit covers is shown in the following figure. The pump pit is constructed from concrete and is located within the ground. The top of the pit extends beyond elevation by approximately six inches while the bottom of the pit extends into the ground six feet. The steel cover blocks are constructed from 2-inch thick A-36 carbon steel and will rest on the edge of the pump pit and existing concrete cover block. The steel cover block is being viewed as falling within the range of a rigid structure, based upon the above description of the application within the field and engineering experience.

Seismic loading for this application is taken from HNF-PRO-097, Engineering Design and Evaluation. While the performance category (PC) for this application falls within the $\mathrm{PC} 1$ and $\mathrm{PC} 2$ range for earthquake loading, implying application of Uniform Building Code seismic zone $2 \mathrm{~B}$ loading. Performance category three (PC3) horizontal accelerations will be used as a measure of conservatism. Only horizontal forces shall be applied to the seismic retraints for the steel cover blocks. Concern has been expressed over the possibility of the steel cover plates to lift off during a seismic event. Thereby, exposing personnel or releasing radioactive spray into the atmosphere. The vertical component of the seismic load is insufficient to overcome the dead weight of the steel cover plates and therefore will not result in the cover plates lifting off of the pump pit. Even under worse case vertical loading, the vertical response spectra does not exceed a value of $1.0 \mathrm{~g}$, thereby the uplifting force cannot exceed the dead weight of the cover plates and the plates will not lift off.

The following calculations validate the use of steel cover plates and their seismic retraints on conformance with existing Hanford Site design requirements.. 
HNF-3433, REV. 0

(1) Drawing (2) Doc. No.

(3) Page of

(4) Building

(5) Rev. (6) Job No.

(7) Subject

PLATE RESTRAINTS

(8) Originator

COVER

(9) Checker

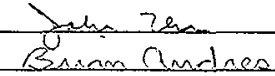
Date Date 9.21 .98

H-2-46150, Sheet 1, Rev. 3: Modify Key Cover Block (241-SX-106) as shown:

NOTE: FIELD TO DETERMINE

LOCATIONS DF PLATE AND

COVER BLOCK.

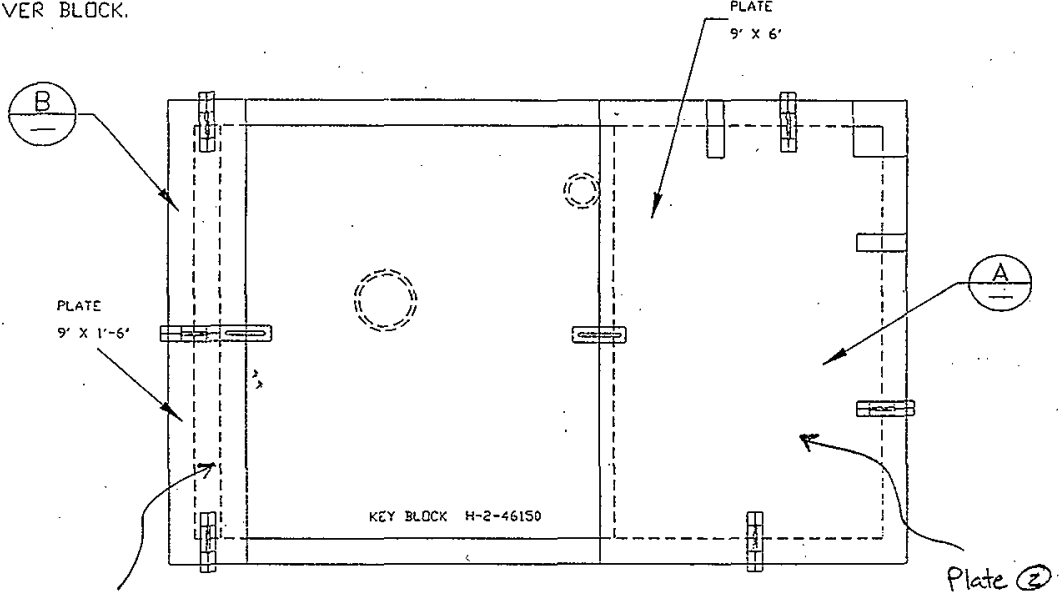

Plate (1)

PLAN PUMP PIT 241-SX-106A DNLY

GENERAL LOCATION

Plate (1) $w_{1}=108 \mathrm{in}(18 \mathrm{~m})(\mathrm{zm})=3888 \mathrm{in}^{3}\left(0.282 \mathrm{~b} / \mathrm{m}^{3}\right)=1096 \mathrm{lb}$

Piate (2) $W_{2}=108 \mathrm{in}(72 \mathrm{n})(2 \mathrm{~m}) \approx 15,552 \mathrm{x}^{3}\left(0.282 \mathrm{k} / \mathrm{m}^{3}\right)=4386 \mathrm{~kb}$ [APPROKEMATE DEMENSTONS]

ALLOWABLE STEESS

ASTM-A36 $\quad \sigma_{u}=36000$ psi $\quad \sigma_{\text {pelt }}=58000$ psi

bending $\sigma_{B_{A 1}}=.6 \sigma_{y}=21600$ psi

shear $z=.4 \mathrm{Fy}=14400 \mathrm{ps}$ :

Page $2 / 6$ 
HNF-3433, REV. 0

DESIGN CALCULATION

(1) Drawing

(2) Doc. No.

(3) Page

of

(4) Building

(5) Rev. (6) Job No.

(7) Subject $241-3 x-106$ COVER PLATE SEISMIC RESTRAINTS

(8) Originator rem Date $\quad 9-2.2 .98$

(9) Checker Ruiniri Andes: Date $9-2>90$

(10) HORIZONTRL LOADS

LATERAL SEISMEL FORCES SHALl BE APPLIED AT $100 \%$ IN BOTH THE NORTH-SOUTH AMD EAST -WEST DIRECTIONS, TO EXERT MAXIMUM DESIGN LOADS UPON SEISMIC RESTRAINTS.

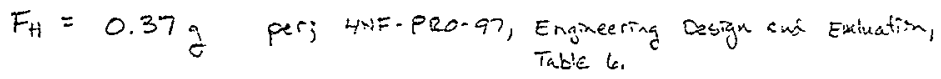

Plate 10

$$
\begin{aligned}
& P_{H}= F_{H} W_{1} \\
& P_{H}=0.37(1096 \mathrm{lb})=406 \mathrm{lb} . \\
& \substack{(\mathrm{N}-\mathrm{s}) \\
(\mathrm{F}-\mathrm{w})}
\end{aligned}
$$

Plate (8) $\quad P_{H}=F_{H} W_{2}$

$$
P_{H}=0.37(438610)=162316 \text { (maximum horizontal) }
$$

RESTEMINT DESIGN

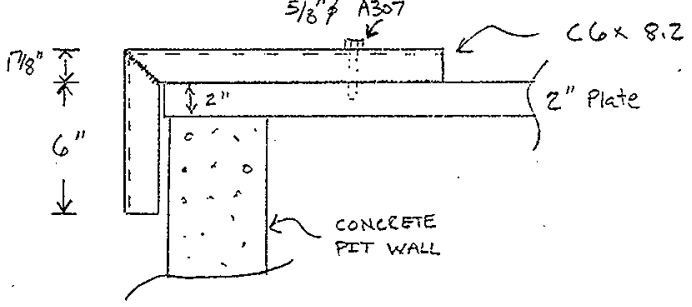

pr; $A=s$ orth Ed.

$$
\frac{y}{E^{x}}
$$$$
S_{x}=4.38 \mathrm{in}^{3}
$$$$
S_{y}=0.492 \mathrm{~m}^{3}
$$

$$
\left\{\begin{array}{l}
l_{1}=\frac{178^{\circ}}{2}+2^{\prime \prime}-2^{\prime \prime} \\
P_{H}
\end{array}\right.
$$

$$
\begin{aligned}
& M_{1}=P_{4} L_{i} \\
& M_{1}=1623 \mathrm{in}(4.9375 \mathrm{~m}) \\
& M_{1}=8014 \mathrm{~m} \cdot 16
\end{aligned}
$$

PAGE $3 / 6$

BO -6400-060.1(12/87) 
HNF-3433, REV. 0

DESIGN CALCULATION

(1) Drawing

(2) DoC. No.

(3) Page of

(4) Building

(5) Rev.

(6) Job No.

(7) Subject 241-SX-106 COVER PLATE SEISMTC RESTRAINTS

(8) Originator

(9) Checker ten

Date 9.22 .98

Date 9.22 .98

(10)

$$
\begin{aligned}
& \text { RESTEATHT DESIGN (COmA) } \\
& \sigma_{b}=M_{y} \\
& T_{t}=\frac{8014 \mathrm{~m} \cdot \mathrm{lb}}{0.492 \mathrm{in}^{3}}=16289 \mathrm{k} / \mathrm{m}^{2} \\
& I R=\frac{\sigma_{0}}{\sigma_{\text {ball }}} \quad \frac{16289 \mathrm{~b} / \mathrm{in}^{2}}{21600 \mathrm{~b} / \mathrm{in}^{2}}
\end{aligned}
$$

ok

C6.8.2 OK TO RESIST BENDING STRESS

WELD DESIGN

WELD DESIGN AND ANALYSTS CONDUCTED PER, "WELDING FORMULAS AND

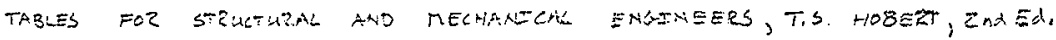

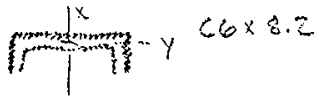

$$
\begin{aligned}
& L=18.6 \mathrm{~m} \\
& S_{x}=29.8^{2} \\
& S_{y}=13.0^{2}
\end{aligned}
$$

$$
f=\frac{P}{L}-\frac{m}{5 y} \quad f=\frac{1623 \mathrm{~b}}{18.6 \mathrm{~m}}+\frac{8014 \mathrm{im} \cdot \mathrm{b}}{13.0 \mathrm{~m}^{2}}=703.7 \mathrm{~b} / \mathrm{in}
$$

FOR ETD ELECTRODE WITH $1 / 8$ " LEG SIRE $f_{\text {all }}=1800 \mathrm{k} / \mathrm{m}$

$$
I R=\frac{f}{f} \quad \frac{703.7 \mathrm{~s} / \mathrm{m}}{1800 \mathrm{~g} / \mathrm{m}}=0.39<10
$$

PAGE $4 / 6$

$80-6400.060 .1(12 / 87)$ 
INF -3433, REV. 0

DESIGN CALCULATION

Page 18 of 19

(1) Drawing

(2) Doc. No.

(3) Page

of

(4) Building

(5) Rev.

(6) Job No.

(7) Subject 241.SX-106 COVER PLATE SEISMTC RESTRAENTS

(8) Originator

(9) Checker

Cram Clanks Date 9.22 .98 Date $9-22-98$

(10)

BOLTING

USE 5/8" DIA, ASTM ABOT BOLTS.

SHEAR AREA EASED UPON THREADS IN THE LOAD PATH!

$$
\begin{aligned}
& A_{s}=\frac{\pi}{4} D_{\operatorname{mix}}^{2} \\
& \text { linin = minor diameter threads } \\
& \text { per; Machinery Handbook }=24 \\
& \text { Table } 3 a, \text { p.1530. } \\
& A_{S}=\frac{\pi}{4}(0.5168 \mathrm{in})^{2}=0.21 \mathrm{in}^{2} \\
& {[0.5168 i x]} \\
& \hat{c}=P / A \quad \frac{1623 \mathrm{~b}}{0.21 \mathrm{~m}^{2}}=7729 \mathrm{~b} / \mathrm{m}^{2} \\
& I R=\frac{\tau^{3}}{\tau_{i}^{3}} \\
& \tau_{\text {ail }}=0 . n \tau_{\text {ult }} \\
& \text { Ne; ADSC in Ed, } \\
& \text { p. 4-5, for threarls } \\
& \text { in sizer fire. } \\
& I R=\frac{7729 \mathrm{~b} / \mathrm{m}^{2}}{0.17\left(60,000 \mathrm{~b} / \mathrm{in}^{4}\right)}=0.76<1.0
\end{aligned}
$$

BOLT SHEAR THROUGH CHANNEL WEB

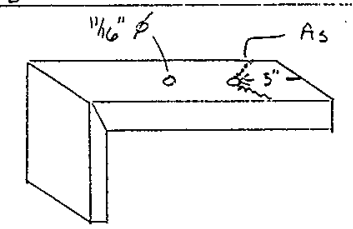

$$
\begin{array}{r}
A_{S}=2\left[+\left(E M-\frac{d}{2} \cos 40\right)\right] \\
A_{S}=2\left[3 / 16^{\prime \prime}\left(3^{\prime \prime}-\frac{11 / 16^{\prime \prime}}{2} \cos 40\right)\right] \\
A_{S}=1.03 \mathrm{~m}^{2}
\end{array}
$$

$$
\begin{aligned}
& \tau=P_{A_{s}} \frac{1623 \mathrm{~b}}{1.03 \mathrm{~m}^{2}}=1576 \mathrm{~b} / \mathrm{in}^{2} \\
& I 2=\frac{\hat{c}}{\tau_{\text {ard }}} \quad \frac{1576 \mathrm{~b} / \mathrm{m}^{2}}{1+400 \mathrm{~b}_{\mathrm{in}}{ }^{2}}=0.11<1.0
\end{aligned}
$$

ok

PAGE $5 / 6$

$60-6400-060.1(12.87)$ 
(1) Drawing

(2) Doc. No.

(3) Page of

(4) Building

(5) Rev.

(6) Job No.

(7) Subject 2411-SX-HOL COVER PLATE SEISMIC: RESTRAINTS

(8) Originator

(9) Checker rem

$$
\text { Date } 9-22-98
$$

Ravin andres $9-2 ?-78$

(10) STEEL PLAE TO CONCRETE COUER BESTRATNT.

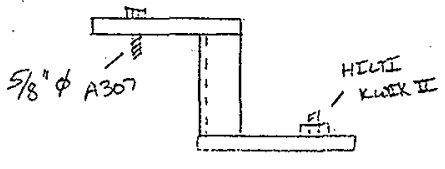

WELD,$\quad F=\frac{P_{U}}{L}+\frac{P_{\nu}}{L}$

$$
f=\frac{16231 \mathrm{~b}}{18.6 \mathrm{~m}}+\frac{1184 \mathrm{~b}}{18.6 \mathrm{~m}}=150.9 \mathrm{k} / \mathrm{m}
$$

$$
I R=\frac{f}{f_{\text {ian }}} \quad \frac{150.9 \mathrm{blin}}{1800 \mathrm{~b} / \mathrm{in}}=0.08<1.0<
$$

HILT BOLT ANALYSTS

$$
\begin{aligned}
& V=P_{H}=1623 \mathrm{lb} \quad \text { per HILTZ Product Technitid Guide, ICBO } \\
& T=P_{Y}=1184 \mathrm{lb} \quad \text { pored expansion anchor. } \\
& \frac{V_{\text {aft }}}{V_{\text {all }}}-\frac{T_{\text {atp }}}{T_{\text {ail }}}<1.0 \\
& \frac{1623 b}{3 \$ 40 !}+\frac{1184 B}{2400 b}=0.92<10^{\text {Tack }}
\end{aligned}
$$

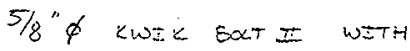

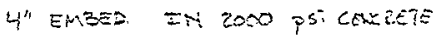

$$
\begin{aligned}
& V_{a} \| l=3840 \mathrm{lb} \\
& T_{a c k}= \pm 400 \mathrm{~b}
\end{aligned}
$$

PACE GIG

SD $-6400-060.1(12 / 87)$ 


\section{DISTRIBUTION SHEET}

To

Distribution

Project Title/Work Order

Design Review Report for ECN 638521 (241-SX-106 Cover Plate Install)
From

Interim Stabilization Engineering

Brown, M. H.

Doeler, J. N.

Johnson, M. N.

Koch, M. R.

Krogsrud, L. S.

Movey, C. B.

Miller, . C.

Volkman, T. J.

Wiggins, D. D.

Zuroff, W. E.

Janicek, G. P.

Page 1 of 1

EDT No. 624831

ECN No. 638521

\begin{tabular}{c|c|c|c|c|} 
MSIN & $\begin{array}{c}\text { Text } \\
\text { With All } \\
\text { Attach. }\end{array}$ & Text Only & $\begin{array}{c}\text { Attach./ } \\
\text { Appendix } \\
\text { Only }\end{array}$ & $\begin{array}{c}\text { EDT/ECN } \\
\text { Only }\end{array}$ \\
\hline
\end{tabular}

T4-07

T4-07

\$7-20

$57-20$

$\mathrm{T} 4-07$

$57-20$

$\mathrm{R} 1-51$

S7-07

$57-20$

$57-20$

$57-12$ $\mathrm{x}$

$x$

$\mathrm{X}$

$x$

$\mathrm{x}$ 